\title{
Association of Solar Irradiance and Days of Precipitation with Incidence of Potato Late Blight in the Semiarid Environment of the Columbia Basin
}

\author{
Dennis A. Johnson and Thomas F. Cummings, Department of Plant Pathology, Washington State University, Pull- \\ man 99164-6430; Rita Abi Ghanem, American University of Beirut, Beirut, Lebanon; and J. Richard Alldredge, \\ Department of Statistics, Washington State University
}

\begin{abstract}
Johnson, D. A., Cummings, T. F., Abi Ghanem, R., and Alldredge, J. R. 2009. Association of solar irradiance and days of precipitation with incidence of potato late blight in the semiarid environment of the Columbia Basin. Plant Dis. 93:272-280.

The effects of cumulative solar irradiance and rainfall on incidence of potato late blight (caused by Phytophthora infestans) in the Columbia Basin of south-central Washington and north-central Oregon were investigated using meteorological data collected near Othello, WA from 1990 through 2007 and Prosser, WA from 1990 through 2006. An association between solar irradiance and seasonal differences in late blight epidemics has not been quantitatively determined. Incidence of late blight in the Columbia Basin significantly increased as cumulative solar irradiance decreased during 1 April to 31 July and 1 June to 31 July at both Othello and Prosser. Incidence of late blight also increased as number of rainy days increased during 1 April to 31 July at Othello and Prosser and from 1 June to 31 July at Prosser. Coefficients of determination for significant models on late bight incidence ranged from 0.28 to 0.43 for cumulative solar irradiance and 0.27 to 0.38 for number of rainy days. Late blight incidence significantly increased as day of the year for first occurrence of late blight decreased in the Columbia Basin. A multiple regression model that included cumulative solar irradiance from 1 June to 31 July at Prosser and day of year for first occurrence of late blight as independent variables accounted for $58 \%$ of the variation for late blight incidence (adjusted $R^{2}=0.58$ ), and a model that included number of cloudy days without rain combined with number of rainy days accounted for $62 \%$ of the variation for late blight incidence. This is the first report demonstrating a quantitative association of solar irradiance and incidence of late blight in commercial potato fields.
\end{abstract}

Late blight, caused by Phytophthora infestans, is a devastating disease of potato in North America and elsewhere in the world. The disease has been present in the Columbia Basin every year since 1990, with the most severe outbreaks occurring in 1993, 1995, 1997, 1998, and 2004. Before 1990, late blight did not occur regularly in this semiarid environment. Several factors have contributed to the recent epidemics of late blight in the region, including the appearance of a population of $P$. infestans that is resistant to the fungicide metalaxyl, highly aggressive on potato, and efficiently transmitted from seed tubers to seed pieces and emerging sprouts (24-27). Above-average precipitation early in the growing season $(19,20)$ and an expanded production of early-season potato

Corresponding author: D. A. Johnson

E-mail: dajohn@wsu.edu

PPNS no. 0400, Department of Plant Pathology, College of Agricultural, Human, and Natural Resource Sciences Agricultural Research Center, Project No. WNPO 0678, Washington State University, Pullman 99164-6430.

Accepted for publication 22 November 2008.

doi:10.1094/PDIS-93-3-0272

(C) 2009 The American Phytopathological Society cultivars that are extremely susceptible to $P$. infestans (15) have likely contributed further to these epidemics. Cost of managing late blight in the Columbia Basin approached $\$ 30$ million in 1995 and was $\$ 22.3$ million in $1998(21,22)$.

The Columbia Basin of south-central Washington and north-central Oregon is a major potato-growing region in North America. The region is isolated and nearly completely bordered by mountains. Over 65,000 ha of potato are grown in the region annually, with mean tuber yields exceeding $74 \mathrm{t} / \mathrm{ha}$ (2). Potato is mainly planted in March through April and harvested from August through October. The environment is semiarid and the potato crop is irrigated mostly by center-pivot systems.

Late blight management in the Columbia Basin is based on an integrated approach that includes using disease-free seed tubers, destroying refuse tubers and volunteer potato plants, treating seed tubers with a fungicide product containing mancozeb or cymoxanil (16), managing irrigation water, adequately hilling soil over developing tubers, applying fungicides to foliage in a timely manner, and harvesting during dry weather (37). Late blight forecasting models coupled with short-range weather forecasts of 3 to 7 days and long-range weather forecasts of 15 to 30 days are utilized to schedule fun- gicide applications for the regions (20). Long-range weather forecasts are obtained from a private weather forecasting group (Fox Weather, LLC, Fortuna, CA). Logistic regression models are used to forecast the probability of late blight occurrence for the Columbia Basin using meteorological data from four vicinities throughout the Basin (20). Indicator variables for the logistic models include the presence of an outbreak during the preceding year and number of rainy days in April and May. Late blight has never been observed in the Columbia Basin before canopy closure between potato rows (row closure). Row closure usually occurs after early June in the Columbia Basin, and sufficient time is given by the forecasting models for growers to implement late bight management tactics.

Disease forecasting models based on leaf wetness or relative humidity and temperature in individual fields such as BLITECAST have not effectively predicted late blight epidemics in the semiarid environments of Washington, Oregon, and Idaho (11,14; unpublished data). Instead, the Columbia Basin late blight forecasting system, which uses logistic regression models $(19,20)$, aids the management of late blight on a regional basis. Regional management of late blight throughout the Columbia Basin is needed because sporangia of $P$. infestans can become airborne in turbulent air currents and be quickly and widely disseminated within the region during cloudy and wet weather $(3,38)$ and, when disease-favoring weather of mild temperatures and rainy conditions occur, they usually prevail over the entire region. In addition, sprinkler irrigation generally creates a favorable microclimate within the potato canopy after closure between rows. As a result, late blight in a field can quickly spread to neighboring fields and then to more distant fields $(4,18)$. Late blight and other rapidly spreading foliar diseases have been forecasted and managed on regional bases $(7,8,14)$.

The role of environment in the development of late blight epidemics is well documented $(4,13,28,33,37)$. Cool, wet weather with rainfall, ambient relative humidity above $90 \%$, and temperatures of 7 to $21^{\circ} \mathrm{C}$ favor late blight development $(23,33)$. Sprinkler irrigation increases late blight in arid and semiarid regions $(11,32,34)$. Leaf wetness is crucial for 
infection, and high humidity in the crop canopy favors sporulation of $P$. infestans; both of these are favored by rainfall and adversely affected by solar irradiance (9,13). Direct exposure to the UVB spectrum is detrimental to $P$. infestans sporangia $(29,30)$. Sporangia of $P$. infestans survived longer in the atmosphere on cloudy days than on sunny days $(29,38)$. Exposure during a 3-h period on sunny days drastically reduced germination of sporangia of $P$. infestans; viability decreased by about $95 \%$ after $1 \mathrm{~h}$ of exposure on sunny days (29). In water suspensions simulating field surface water, sporangia of $P$. infestans survived for up to 21 days, and shade contributed to an increase in survivability of sporangia (30). Also, sporangia survived significantly longer in soil under shaded verses nonshaded field conditions (31).

An association between solar irradiance and seasonal differences in late blight epidemics has not been quantitatively determined. Our hypothesis is that late blight occurrence in the semiarid environment of the Columbia Basin is negatively associated with solar irradiance. The purpose of this study was to investigate a possible association of solar irradiance with incidence of late blight in the semiarid environment of the Columbia Basin using regression analysis, and to investigate the feasibility of using solar irradiance in predictive models for late blight incidence.

\section{MATERIALS AND METHODS}

Meteorological data were collected at the Washington State University Irrigated Research and Extension Centers near Othello, WA, from 1990 through 2007 and Prosser, WA, from 1990 through 2006. Data were not collected from Prosser in 2007 because instrumentation malfunctioned. Othello is approximately $106 \mathrm{~km}$ north-northeast of Prosser, and the two locations represent the north and south regions of the Columbia Basin, respectively (20). Variables used were number of days with rainfall $\geq 0.25 \mathrm{~mm}$, total precipitation, and cumulative daily solar irradiance in megajoules per square meter $\left(\mathrm{MJ} / \mathrm{m}^{2}\right)$. Rainfall was measured with a tipping bucket rain gauge (Weathertronics Weather, Sacramento, CA at Othello and Texas Electronics, Dallas at Prosser). Solar irradiance was measured with a pyranometer (LI-200SA; LI-COR, Inc., Lincoln, $\mathrm{NE})$. Meteorological conditions were measured every $10 \mathrm{~s}$ and averaged over a 60 -min period. The 60 -min means for solar irradiance were summed for each day to give total $\mathrm{MJ} / \mathrm{m}^{2}$. These variables were selected to investigate a possible association of solar irradiance with incidence of late blight in the Columbia Basin for several reasons. First, solar irradiance was selected as a measure of solar radiation. Second, the number of rainy days is a key variable in the logistic models currently used to forecast the probability of late blight occurrence in the Columbia Basin $(19,20)$. Third, variables were desired that fit the approach of forecasting and managing late blight on a regional bases. Fourth, accurate determination of leaf wetness and humidity within plant canopies is inherently difficult and costly (1) and an approach was desired that did not rely on those variables.

Total precipitation, number of rainy days, and cumulative daily total solar irradiance were determined for the time periods of 1 April to 31 May, 1 April to 30 June, 1 April to 31 July, 1 April to $31 \mathrm{Au}$ gust, 1 May to 31 May, 1 May to 30 June, 1 May to 31 July, 1 May to 31 August, 1 June to 31 July, 1 June to 31 August, and 1 July to 31 August. Time periods were selected to partition the growing season into regular segments to help determine when the selected meteorological factors might influence late blight incidence. Overlapping time periods were used because, previously, sequences of variable, overlapping time segments of 21 to 65 days were successfully used to identify meteorological factors associated with occurrence of stripe rust of wheat (8).

To more fully explore the possible association between reduced solar irradiance and incidence of late blight, individual days from 1 April through 31 July were classified as either "cloudy" or "noncloudy" based on daily solar irradiance. A cloudy day was defined as a day within a given month with daily solar irradiance $\leq$ the median $\mathrm{MJ} / \mathrm{m}^{2}$ for all days with measurable rainfall within that month during the time period of the study, which was 1990 to 2007 at Othello and 1990 to 2006 at Prosser. Monthly segments were used because $\mathrm{MJ} / \mathrm{m}^{2}$ for days increases as the day length increases (Table 1). Then, the number of days classified as cloudy, the number of days classified as cloudy but with no rain, and the number of cloudy days with no rain combined with the number of rainy days were determined for 1 April to July 31 and 1 June to July 31 at both Othello and Prosser. In addition, the number of two consecutive days with measurable rainfall (rain couplet) and the number of two consecutive days consisting of one of the following: rainy day/rainy day, rainy day/cloudy day, and cloudy day/rainy day and cloudy day/cloudy day (rain/cloudy couplet) during 1 April to 31
July and 1 June to 31 July were identified at both Othello and Prosser. The respective time segments of April through July and June through July were selected because they were the only time periods of the previously mentioned 11 time periods evaluated in which number of rainy days and cumulative solar irradiance at Othello and Prosser were significantly associated with late blight incidence in the Columbia Basin.

The date recorded as the first occurrence of late blight was the date during each year of the study period (1990 to 2007) when late blight was first observed by $\mathrm{D}$. A. Johnson or reported to him by growers, field persons, or consultants and then observed and confirmed by D. A. Johnson or another qualified plant pathologist. Most potato fields in the Columbia Basin are regularly monitored several times each week during the growing season by growers, field persons, or consultants. Any observance or suspected occurrence of late blight is reported to D. A. Johnson as part of the late blight warning system in the Columbia Basin. All calendar dates were converted to day of the year, in which 1 January $=1$ and 31 December $=365$, or 366 in leap years $(8,36)$.

Incidence of late blight in the Columbia Basin was estimated for each of the study years (1990 to 2007) by estimating the number and size of potato fields in the Columbia Basin of Washington and Oregon with late blight from disease surveys conducted by D. A. Johnson and from interviewing Extension personnel, field persons, and consultants who regularly visited potato fields. Total land area cropped to potato each year was obtained from the Washington State Potato Commission. Late blight incidence for each year was calculated by dividing the total size of all known fields with late blight by the total area cropped to potato in the Columbia Basin. Only potato fields with at least a $1-\mathrm{m}^{2}$ area with late-blight-infected foliage were classified as being infected with late blight. Field persons and consultants can detect late blight at this level when monitoring the crop for diseases or field conditions such as soil moisture level. Potato fields in the Columbia Basin typically range in size from 11 to 51 ha, and at least $98 \%$ of the potato fields in the Basin were included in the surveys during the

Table 1. Median cumulative daily solar irradiance of individual days with and without measureable rainfall during April, May, June, and July from 1990 to 2007 at Othello and 1990 to 2006 at Prosser

\begin{tabular}{lccccc}
\hline & \multicolumn{4}{c}{ Solar irradiance $\left(\mathbf{M J} / \mathbf{m}^{2}\right)$} \\
\cline { 2 - 3 } \cline { 5 - 6 } Month & \multicolumn{2}{c}{ Othello } & & \multicolumn{2}{c}{ Prosser } \\
\cline { 2 - 3 } \cline { 5 - 6 } & With rain & Without rain & & With rain & Without rain \\
\hline April & 14.17 & 19.39 & & 15.10 & 21.31 \\
May & 15.60 & 24.34 & & 16.66 & 26.98 \\
June & 20.31 & 27.44 & & 20.21 & 29.64 \\
July & 24.59 & 27.13 & & 22.93 & 29.48 \\
Mean & 18.67 & 24.57 & & 18.73 & 26.85 \\
\hline
\end{tabular}


Table 2. Date, day of year (DOY), and location of the first occurrence of late blight and incidence of late blight in the Columbia Basin from 1990 to 2007

\begin{tabular}{|c|c|c|c|c|}
\hline \multirow[b]{2}{*}{ Year } & \multicolumn{2}{|c|}{ First occurrence } & \multirow[b]{2}{*}{ Location } & \multirow[b]{2}{*}{ Incidence $(\%)^{b}$} \\
\hline & Date & DOY $^{a}$ & & \\
\hline 1990 & August 15 & 227 & Moses Lake & 0.4 \\
\hline 1991 & August 14 & 226 & Hermiston & 24 \\
\hline 1992 & July 7 & 189 & N. Pasco & 42 \\
\hline 1993 & June 18 & 173 & Hermiston & 45 \\
\hline 1994 & July 15 & 196 & N. Pasco & 1.1 \\
\hline 1995 & June 5 & 156 & Hermiston & 80 \\
\hline 1996 & July 3 & 184 & Hermiston & 44 \\
\hline 1997 & June 16 & 167 & N. Pasco & 70 \\
\hline 1998 & June 15 & 166 & N. Pasco & 64 \\
\hline 1999 & August 8 & 220 & Othello & 5.0 \\
\hline 2000 & July 15 & 197 & Royal City & 13 \\
\hline 2001 & July 31 & 212 & NE Pasco & 0.6 \\
\hline 2002 & June 6 & 157 & Burbank & 1.8 \\
\hline 2003 & June 25 & 176 & N. Pasco & 3.0 \\
\hline 2004 & June 24 & 176 & N. Pasco & 35 \\
\hline 2005 & July 15 & 196 & Finley & 22 \\
\hline 2006 & June 17 & 168 & Eltopia & 5.7 \\
\hline 2007 & August 22 & 233 & Eltopia & 0.6 \\
\hline
\end{tabular}

a All calendar dates were converted to DOY, in which 1 January $=1$ and 31 December $=365$, or 366 in leap years (36)

b Total area of all potato fields with at least a $1-\mathrm{m}^{2}$ area with late-blight-infected foliage divided by total area cropped to potato in the Columbia Basin. study period. Severity of late blight greater than the $1-\mathrm{m}^{2}$ threshold was not recorded because of time constraints required to consistently estimate late blight severity over many fields in a large geographic area.

Pearson's correlation was used to explore the relationships between selected meteorological variables at Othello from 1990 to 2007 and at Prosser from 1990 to 2006, and to explore the relationships between the selected variables and first incidence of late blight in the Columbia Basin. The selected meteorological variables were cumulative solar irradiance, number of rain days with rainfall $>0.25 \mathrm{~mm}$, number of cloudy days, number of cloudy days with no rain, number of cloudy days with no rain combined with number of rainy days, number of rain couplets, and number of rain-cloudy couplets during 1 April to 31 July and 1 June to 31 July.

Linear regression analyses were used to investigate the effects of selected meteorological variables on development of late blight in the Columbia Basin using the

Table 3. Cumulative solar irradiance (CSI), number of rainy days, number of cloudy days, number of cloudy days with no rain (Cloudy, no rain), and number of rainy days plus number of cloudy days with no rain (Cloudy + rain) at Othello and Prosser, WA from 1990 through 2007

\begin{tabular}{|c|c|c|c|c|c|c|c|c|c|c|}
\hline \multirow[b]{3}{*}{ Location, year } & \multirow{2}{*}{\multicolumn{2}{|c|}{$\operatorname{CSI}\left(\mathbf{M J} / \mathbf{m}^{2}\right)$}} & \multicolumn{8}{|c|}{ Number of } \\
\hline & & & \multicolumn{2}{|c|}{ Rainy days } & \multicolumn{2}{|c|}{ Cloudy days ${ }^{a}$} & \multicolumn{2}{|c|}{ Cloudy, no rain } & \multicolumn{2}{|c|}{ Cloudy + rain } \\
\hline & April-July & June-July & April-July & June-July & April-July & June-July & April-July & June-July & April-July & June-July \\
\hline \multicolumn{11}{|l|}{ Othello } \\
\hline 1990 & 2,658 & 1,495 & 26 & 8 & 27 & 16 & 11 & 9 & 37 & 17 \\
\hline 1991 & 2,635 & 1,479 & 22 & 9 & 28 & 14 & 16 & 8 & 38 & 17 \\
\hline 1992 & 2,676 & 1,432 & 22 & 13 & 26 & 18 & 11 & 9 & 33 & 22 \\
\hline 1993 & 2,560 & 1,421 & 37 & 15 & 39 & 25 & 18 & 16 & 55 & 31 \\
\hline 1994 & 2,744 & 1,572 & 26 & 10 & 23 & 9 & 10 & 4 & 36 & 14 \\
\hline 1995 & 2,644 & 1,431 & 32 & 13 & 34 & 20 & 14 & 11 & 46 & 24 \\
\hline 1996 & 2,750 & 1,568 & 27 & 11 & 20 & 10 & 9 & 7 & 36 & 18 \\
\hline 1997 & 2,628 & 1,489 & 35 & 23 & 29 & 15 & 16 & 7 & 51 & 30 \\
\hline 1998 & 2,659 & 1,541 & 35 & 14 & 29 & 10 & 12 & 4 & 47 & 18 \\
\hline 1999 & 2,775 & 1,541 & 23 & 12 & 23 & 10 & 14 & 6 & 37 & 18 \\
\hline 2000 & 2,720 & 1,534 & 23 & 9 & 20 & 11 & 11 & 6 & 34 & 15 \\
\hline 2001 & 2,885 & 1,575 & 25 & 10 & 19 & 10 & 7 & 4 & 32 & 14 \\
\hline 2002 & 2,869 & 1,602 & 33 & 19 & 19 & 9 & 8 & 4 & 41 & 23 \\
\hline 2003 & 2,749 & 1,606 & 16 & 1 & 26 & 11 & 19 & 11 & 35 & 12 \\
\hline 2004 & 2,705 & 1,547 & 25 & 8 & 23 & 12 & 14 & 8 & 38 & 15 \\
\hline 2005 & 2,684 & 1,701 & 22 & 11 & 35 & 10 & 22 & 4 & 44 & 16 \\
\hline 2006 & 2,819 & 1,648 & 29 & 12 & 29 & 9 & 10 & 2 & 39 & 14 \\
\hline 2007 & 2,951 & 1,625 & 7 & 0 & 19 & 11 & 15 & 11 & 22 & 11 \\
\hline \multicolumn{11}{|l|}{ Proser } \\
\hline 1990 & 2,879 & 1,619 & 21 & 9 & 20 & 10 & 10 & 6 & 31 & 15 \\
\hline 1991 & 2,852 & 1,596 & 20 & 9 & 23 & 8 & 11 & 2 & 31 & 11 \\
\hline 1992 & 2,946 & 1,597 & 23 & 11 & 18 & 10 & 7 & 4 & 30 & 15 \\
\hline 1993 & 2,816 & 1,552 & 29 & 9 & 27 & 12 & 10 & 7 & 39 & 16 \\
\hline 1994 & 3,017 & 1,717 & 23 & 7 & 14 & 4 & 3 & 1 & 26 & 8 \\
\hline 1995 & 2,943 & 1,601 & 35 & 15 & 23 & 9 & 5 & 2 & 40 & 17 \\
\hline 1996 & 2,996 & 1,698 & 23 & 6 & 18 & 6 & 6 & 3 & 29 & 9 \\
\hline 1997 & 2,915 & 1,637 & 20 & 10 & 18 & 9 & 11 & 5 & 31 & 15 \\
\hline 1998 & 2,838 & 1,635 & 25 & 7 & 26 & 10 & 10 & 7 & 35 & 14 \\
\hline 1999 & 3,079 & 1,707 & 16 & 6 & 14 & 4 & 10 & 3 & 26 & 9 \\
\hline 2000 & 3,041 & 1,711 & 22 & 6 & 12 & 4 & 4 & 1 & 26 & 7 \\
\hline 2001 & 2,989 & 1,650 & 23 & 9 & 21 & 9 & 9 & 4 & 32 & 13 \\
\hline 2002 & 3,061 & 1,720 & 17 & 7 & 12 & 4 & 8 & 1 & 25 & 8 \\
\hline 2003 & 3,116 & 1,801 & 11 & 0 & 9 & 2 & 7 & 2 & 18 & 2 \\
\hline 2004 & 3,027 & 1,717 & 19 & 6 & 14 & 5 & 7 & 2 & 26 & 8 \\
\hline 2005 & 2,971 & 1,709 & 26 & 8 & 25 & 8 & 10 & 4 & 36 & 12 \\
\hline 2006 & 3,010 & 1,720 & 19 & 6 & 20 & 5 & 6 & 0 & 25 & 6 \\
\hline
\end{tabular}

a Based on monthly median solar radiation for days with measurable rainfall. Median cloudy values $($ MJ) for Prosser: April = 15.10 , May = 16.66, June = 20.21, July =22.93; MJ for Othello: April = 14.17, May = 15.60, June = 20.31, July = 24.59. 
REG procedure of SAS (SAS Release 8.0; SAS Institute, Cary, NC). Incidence of late blight was the dependent variable. Data for day of year of first occurrence (FO) of late blight in the Columbia Basin, cumulative daily solar irradiance, number of days with rainfall $\geq 0.25 \mathrm{~mm}$, total precipitation, number of cloudy days, number of cloudy days with no rain, number of cloudy days combined with number of rainy days, number of rain couplets, and number of rain-cloudy couplets were used as independent variables. Scatter diagrams, coefficients of determination $\left(R^{2}\right)$, and overall analysis of variance $F$ tests were used to select independent variables for linear regression. The significance of adding a second independent variable to a model was $0.05 \operatorname{Pr}>|t|$ for that parameter estimate.

Multicollinearity between the independent variables of cumulative solar irradiance, number of rainy days, and day of FO of late blight for the various time periods was examined by variance inflation factors and variance proportions (5) using the VIF and COLLINOINT options in PROC REG, SAS statistical software (SAS Institute).

To help distinguish the effects of cumulative solar irradiance and number of rainy days on incidence of late blight in the Columbia Basin, regression models using the dependent variable of late blight incidence with the independent variables of cumulative solar irradiance, number of rainy days, and day of year of FO of late blight were compared. The best one, two, and three independent variables model for weather data collected 1 April to July 31 and 1 May to July 31 at each Othello and Prosser were identified using $R^{2}$ selection, Mallows $\mathrm{C}(\mathrm{P})$ statistic, and forward selection methods (12).

\section{RESULTS}

Data summaries. The earliest FO of late blight in the Columbia Basin during the study period was 5 June 1995 . The latest FO of the disease was 22 August 1997. The highest incidence of late blight was $80 \%$, which occurred in 1995 , and the lowest incidence during the study period was $0.4 \%$ in 1990 (Table 2). Annual late blight incidence increased significantly as day of the year of FO of late blight decreased. Coefficient of determination was 0.32 with $P=0.015(n=18)$ for data collected at Othello and 0.28 with $P=0.030$ $(n=17)$ for data at Prosser.

Cumulative solar irradiance during April through July was greatest at Othello in 2007 and at Prosser in 1999 (Table 3). In total, $51 \%$ of the cloudy days at Othello ( $n$ $=18$ years $)$ and $43 \%$ of the cloudy days at Prosser ( $n=17$ years) did not receive rain during April through July. There were more rainy days and cloudy days at Othello than Prosser during April through July (Table 3 ). The mean number of rainy days was 25.8 at Othello and 21.9 at Prosser, and the mean number of cloudy days was 26.0 at Othello and 18.5 at Prosser. The number of days classified as cloudy with no rain during April through July varied from 7 to 22 and 4 to 11 at Othello and Prosser, respectively, and during June and July from 2 to 16 and 0 to 7 at Othello and Prosser, respectively (Table $3)$. The number of cloudy days with no rain plus rainy days was greatest in 1993, a

Table 4. Pearson's correlation coefficients for relationships between selected meteorological variables and day of year of first occurrence (FO) of late blight at each of two locations in the Columbia Basin

\begin{tabular}{|c|c|c|c|c|c|c|}
\hline \multirow[b]{3}{*}{ Variables } & \multirow[b]{3}{*}{ Period } & \multicolumn{5}{|c|}{ Correlation coefficients $^{\mathrm{a}}$} \\
\hline & & \multicolumn{2}{|c|}{ Solar irradiance } & \multicolumn{2}{|c|}{ Rainy days } & \multirow[b]{2}{*}{ Late blight $\mathbf{F O}^{\mathrm{b}}$} \\
\hline & & April-July & June-July & April-July & June-July & \\
\hline \multicolumn{7}{|l|}{ Othello 1990-2007 } \\
\hline Solar irradiance ${ }^{c}$ & April-July & $\ldots$ & $\ldots$ & $\ldots$ & $\ldots$ & 0.26 \\
\hline Solar irradiance & June-July & $\ldots$ & $\ldots$ & $\ldots$ & $\ldots$ & 0.09 \\
\hline No. of rainy days ${ }^{\mathrm{d}}$ & April-July & $-0.51^{*}$ & $\ldots$ & $\ldots$ & $\ldots$ & $-0.67 * *$ \\
\hline No. of rainy days & June-July & $\ldots$ & -0.33 & $\ldots$ & $\ldots$ & $-0.55^{*}$ \\
\hline No. of cloudy days ${ }^{\mathrm{e}}$ & April-July & $-0.75 * *$ & $\ldots$ & 0.44 & $\ldots$ & -0.33 \\
\hline No. of cloudy days & June-July & $\ldots$ & $-0.82 * *$ & $\ldots$ & 0.23 & -0.15 \\
\hline No. of cloudy w/no rain ${ }^{\mathrm{f}}$ & April-July & -0.44 & $\ldots$ & -0.20 & $\ldots$ & 0.02 \\
\hline No. of cloudy w/no rain & June-July & $\ldots$ & $-0.58 *$ & $\ldots$ & -0.24 & 0.04 \\
\hline No. of cloudy w/rainy days ${ }^{\mathrm{g}}$ & April-July & $-0.73 * *$ & $\ldots$ & $0.86^{* *}$ & $\ldots$ & $-0.63 * *$ \\
\hline No. of cloudy w/rainy days & June-July & $\ldots$ & $-0.65 * *$ & $\ldots$ & $0.80 * *$ & $-0.49 *$ \\
\hline No. of rain couplets ${ }^{\mathrm{h}}$ & April-July & $-0.57 *$ & $\ldots$ & $0.92 * *$ & $\ldots$ & $-0.76^{* *}$ \\
\hline No. of rain couplets & June-July & $\ldots$ & -0.41 & $\ldots$ & $0.93 * *$ & $-0.57 *$ \\
\hline No. of rain-cloudy couplets ${ }^{i}$ & April-July & $-0.73 * *$ & $\ldots$ & $0.69 * *$ & $\ldots$ & $-0.58 *$ \\
\hline No. of rain-cloudy couplets & June-July & $\ldots$ & $-0.63 * *$ & $\ldots$ & $0.67 * *$ & -0.45 \\
\hline \multicolumn{7}{|l|}{ Prosser 1990-2006 } \\
\hline Solar irradiance & April-July & $\ldots$ & $\ldots$ & $\ldots$ & $\ldots$ & -0.06 \\
\hline Solar Irradiance & June-July & $\ldots$ & $\ldots$ & $\ldots$ & $\ldots$ & -0.10 \\
\hline No. of rainy days & April-July & $-0.58 *$ & $\ldots$ & $\ldots$ & $\ldots$ & -0.21 \\
\hline No. of rainy days & June-July & $\ldots$ & $-0.80 * *$ & $\ldots$ & $\ldots$ & -0.04 \\
\hline No. of cloudy days & April-July & $-0.85 * *$ & $\ldots$ & $0.72 * *$ & $\ldots$ & $<0.01$ \\
\hline No. of cloudy days & June-July & $\ldots$ & $-0.91 * *$ & $\ldots$ & $0.72 * *$ & 0.04 \\
\hline No. of cloudy w/no rain & April-July & $-0.51 *$ & $\ldots$ & -0.11 & $\ldots$ & 0.27 \\
\hline No. of cloudy w/no rain & June-July & $\ldots$ & $-0.61 * *$ & $\ldots$ & 0.27 & 0.09 \\
\hline No. of cloudy w/rainy days & April-July & $-0.78 * *$ & $\ldots$ & $0.90 * *$ & $\ldots$ & -0.08 \\
\hline No. of cloudy w/rainy days & June-July & $\ldots$ & $-0.90 * *$ & $\ldots$ & $0.87 * *$ & 0.01 \\
\hline No. of rain couplets & April-July & -0.19 & $\ldots$ & $0.62 * *$ & $\ldots$ & -0.17 \\
\hline No. of rain couplets & June-July & $\ldots$ & -0.43 & $\ldots$ & $0.69 * *$ & -0.22 \\
\hline No. of rain-cloudy couplets & April-July & $-0.59 *$ & $\ldots$ & $0.66 * *$ & $\ldots$ & -0.06 \\
\hline No. of rain-cloudy couplets & June-July & $\ldots$ & $-0.80 * *$ & $\ldots$ & $0.85^{* *}$ & -0.18 \\
\hline
\end{tabular}

a Asterisks: $*$ and $* *=$ model significant at $0.05>P<0.01$ and $P<0.01$, respectively.

${ }^{\mathrm{b}}$ Based on day of the year of the FO of late blight in the Columbia Basin.

${ }^{\mathrm{c}}$ Sum of daily hourly means of solar radiation $\left(\mathrm{MJ} / \mathrm{m}^{2}\right)$ for specific climate period.

${ }^{\mathrm{d}}$ Number days with $>0.25 \mathrm{~mm}$ of rain for specific period.

${ }^{\mathrm{e}}$ Number of days with less than the daily median of solar radiation for days that received rain weighted for each month.

${ }^{\mathrm{f}}$ Number of defined cloudy days in which there was no rain.

$\mathrm{g}$ Number of defined cloudy days in which there was no rain added to the number days with $>0.25 \mathrm{~mm}$ of rain.

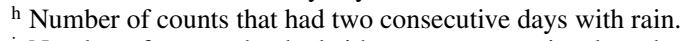

i Number of counts that had either two consecutive days that were defined as cloudy or rain or a combination of cloudy and rain. 
year with the fourth highest late blight incidence (Table 2) during both April through July and during June and July at both locations (Table 3 ).

Correlations. Cumulative solar irradiance and number of rainy days were sig-

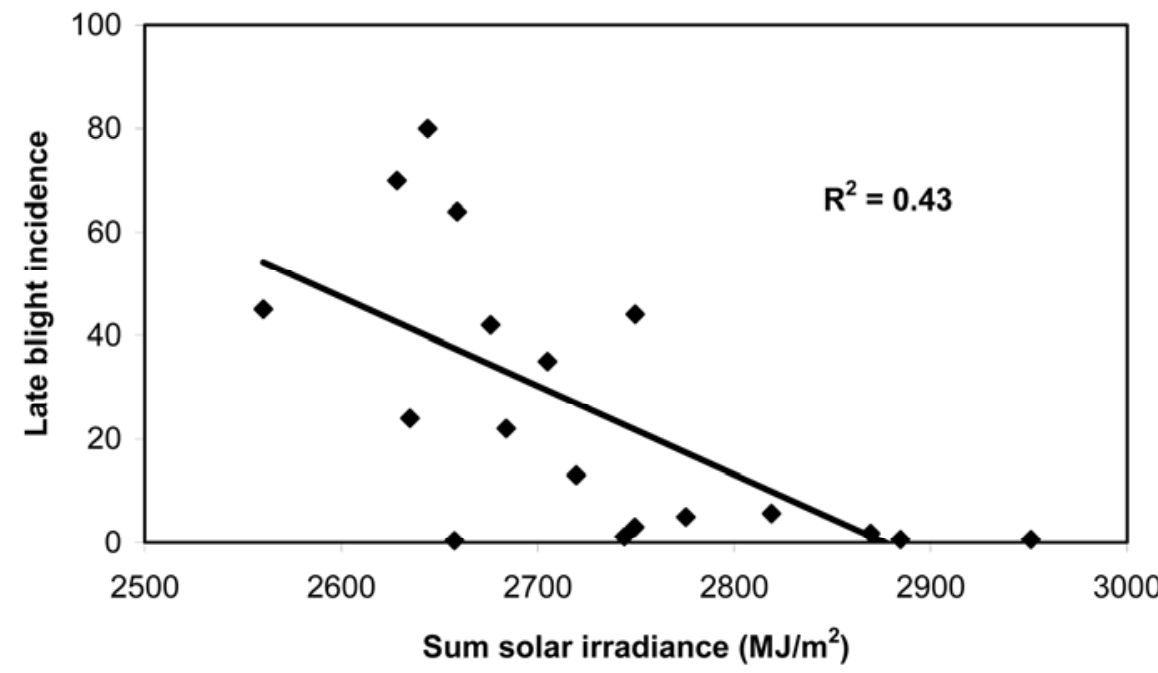

Fig. 1. Incidence of late blight in relation to cumulative solar irradiance at Othello during April through July from 1990 to 2007. nificantly correlated at Othello from 1 April to 31 July and both time periods at Prosser $(P<0.05$; Table 4). Cumulative solar irradiance was significantly correlated with cloudy days at both Othello and Prosser during both time periods $(P<$
0.01; Table 4). Number of rainy days were not significantly correlated with number of cloudy days at Othello during both time periods $(P>0.05)$ but they were correlated at Prosser $(P<0.01$; Table 4$)$. The number of rain couplets was not significantly correlated with cumulative solar irradiance during June and July at Othello and for neither time period at Prosser (Table 4). Number of rainy days was significantly correlated with day of the year of FO of late blight at Othello but not Prosser (Table 4).

Simple linear regressions. Incidence of late blight significantly increased as cumulative solar irradiance decreased during 1 April to 31 July and 1 June to 31 July at both Othello and Prosser (Fig. 1; Table 5). Incidence of late blight also increased as number of rainy days increased during 1 April to 31 July at Othello and Prosser and from 1 June to 31 July only at Prosser (Table 5). Significant regressions $(P>$ $0.05)$ were not identified using either cumulative solar irradiance or number of rainy days as independent variables at either location during nine time periods (1 April to 31 May, 1 April to 30 June, 1 April to 31 August, 1 May to 31 May, 1

Table 5. Coefficients of determination and probability of significance when one- and two-independent-variable models were regressed with incidence of late blight in the Columbia Basin

\begin{tabular}{|c|c|c|c|c|c|}
\hline Models & Period & Second variable ${ }^{a}$ & $\operatorname{Pr}>F$ & $R^{2}$ & $\operatorname{Adj} . R^{2}$ \\
\hline \multicolumn{6}{|l|}{ Single variable } \\
\hline \multicolumn{6}{|l|}{ Othello } \\
\hline $\mathrm{FO}^{\mathrm{b}}$ & $\ldots$ & $\ldots$ & 0.015 & 0.32 & $\ldots$ \\
\hline Solar irradiance $\mathrm{c}$ & April-July & $\ldots$ & 0.003 & 0.43 & $\ldots$ \\
\hline Solar irradiance & June-July & $\ldots$ & 0.014 & 0.32 & $\ldots$ \\
\hline No. of rain days ${ }^{\mathrm{d}}$ & April-July & $\ldots$ & 0.016 & 0.31 & $\ldots$ \\
\hline No. of rain days & June-July & $\ldots$ & 0.027 & 0.27 & $\ldots$ \\
\hline No. of cloudy days ${ }^{\mathrm{e}}$ & April-July & $\ldots$ & 0.025 & 0.28 & $\ldots$ \\
\hline No. of cloudy days & June-July & $\ldots$ & 0.024 & 0.28 & $\ldots$ \\
\hline No. of cloudy days w/no rain $\mathrm{f}$ & April-July & $\ldots$ & 0.400 & 0.05 & $\ldots$ \\
\hline No. of cloudy days w/no rain & June-July & $\ldots$ & 0.264 & 0.08 & $\ldots$ \\
\hline No. of cloudy w/rainy days ${ }^{\mathrm{g}}$ & April-July & $\ldots$ & 0.004 & 0.42 & $\ldots$ \\
\hline No. of cloudy w/rainy days & June-July & $\ldots$ & 0.003 & 0.44 & $\ldots$ \\
\hline No. of couplets (rain) ${ }^{\mathrm{h}}$ & April-July & $\ldots$ & 0.001 & 0.51 & $\ldots$ \\
\hline No. of couplets (rain) & June-July & $\ldots$ & 0.005 & 0.40 & $\ldots$ \\
\hline No. of couplets (rain/cloudy) ${ }^{\mathrm{i}}$ & April-July & $\ldots$ & 0.004 & 0.42 & $\ldots$ \\
\hline No. of couplets (rain/cloudy) & June-July & $\ldots$ & 0.019 & 0.30 & $\ldots$ \\
\hline \multicolumn{6}{|l|}{ Prosser } \\
\hline FO & $\ldots$ & $\ldots$ & 0.030 & 0.28 & $\ldots$ \\
\hline Solar irradiance & April-July & $\ldots$ & 0.027 & 0.28 & $\ldots$ \\
\hline Solar irradiance & June-July & $\ldots$ & 0.025 & 0.29 & $\ldots$ \\
\hline No. of rainy days & April-July & $\ldots$ & 0.009 & 0.38 & $\ldots$ \\
\hline No. of rainy days & June-July & $\ldots$ & 0.020 & 0.31 & $\ldots$ \\
\hline No. of cloudy days & April-July & $\ldots$ & 0.048 & 0.24 & $\ldots$ \\
\hline No. of cloudy days & June-July & $\ldots$ & 0.021 & 0.31 & $\ldots$ \\
\hline No. of cloudy days w/no rain & April-July & $\ldots$ & 0.635 & 0.02 & $\ldots$ \\
\hline No. of cloudy days w/no rain & June-July & $\ldots$ & 0.104 & 0.17 & $\ldots$ \\
\hline No. of cloudy w/rainy days & April-July & $\ldots$ & 0.006 & 0.40 & $\ldots$ \\
\hline \multirow[t]{2}{*}{ No. of cloudy w/rainy days } & June-July & $\ldots$ & 0.008 & 0.38 & $\ldots$ \\
\hline & & & & \multicolumn{2}{|c|}{ (continued on next page) } \\
\hline
\end{tabular}

a Asterisk $(*)=$ the second independent variable was significant for that parameter estimate at $0.05 \operatorname{Pr}>|\mathrm{t}|$.

${ }^{\mathrm{b}}$ Based on day of year of the first occurrence (FO) of late blight in the Columbia basin; Othello, $n=18$ and Prosser, $n=17$.

${ }^{c}$ Sum of the daily hourly means of solar radiation $\left(\mathrm{MJ} / \mathrm{m}^{2}\right)$ for specific climate period.

$\mathrm{d}$ Number days with $>0.25 \mathrm{~mm}$ of rain.

${ }^{\mathrm{e}}$ Number of days with less than the daily median of solar radiation for days that received rain weighted for each month.

${ }^{\mathrm{f}}$ Number of defined cloudy days in which there was no rain.

$\mathrm{g}$ Number of defined cloudy days in which there was no rain added to the number days with $>0.25 \mathrm{~mm}$ of rain

${ }^{\mathrm{h}}$ Number of counts that had two consecutive days with rain.

${ }^{i}$ Number of counts that had either two consecutive days that were defined as cloudy or rain or combination of cloudy and rain. 
May to 30 June, 1 May to 31 July, 1 May to 31 August, 1 June to 31 August, and 1 July to 31 August; data not shown). Total precipitation was not significantly related $(P>0.05)$ with incidence of late blight during any of the time periods examined (data not shown).

Multiple regressions. Multiple regression equations that included cumulative solar irradiance and day of year of FO of late blight as independent variables accounted for 53 to $58 \%$ (adjusted $R^{2}=0.53$ to 0.58 ) of the variation for late blight incidence during the two time periods at the two locations (Table 5). Each variable was significantly related to late blight incidence for each of the four models at both time periods $(P<0.05)$. The two variable regression models that included number of rainy days and day of year of FO of late blight as independent variables accounted for 48 to $50 \%$ of the variation in late blight incidence at Prosser for both time periods (Table 5). Each variable was significantly related to late blight incidence in each of the two time periods at Prosser $(P<0.05)$. Significant variation in late blight incidence $(P>0.05)$ was not explained by rainy days when the independent variable FO was included in the model at Othello for both time periods.
Two variable regression equations that included number of cloudy days without rain combined with rainy days during June and July at Prosser as the first independent variable and day of year of FO of late blight as the second independent variable accounted for $62 \%$ of the variation for late blight incidence; the number of raincloudy couplets during June and July at Prosser as the first independent variable and FO as the second independent variable accounted for $59 \%$ of the variation for late blight incidence (Table 5). Regression equations for selected models are shown in Table 6.

Significant variation for incidence of late blight was accounted for in two variable regressions using both cumulative solar irradiance and number of rainy days as independent variables (Table 5). Adjusted coefficients of determination were $0.43(P=0.006)$ during April through July and $0.37(P=0.012)$ during June through July at Othello. Adjusted coefficient of determination was $0.34(P=0.021)$ during April through July at Prosser. The twovariable regression model with solar irradiance and number of rainy days was not significant $(P>0.05)$ during June and July at Prosser. Cumulative solar irradiance was significantly related to incidence of late blight for the two time periods at Othello but the second independent variable, number of rainy days, was not significant (Table 5). Collinearity was not significant between cumulative solar irradiance and number of rainy days during 1 April to 31 July and 1 June to 31 July at Othello and Prosser.

At Othello during both time periods, cumulative solar irradiance was selected by both the $R^{2}$ section method and the Mallow statistic $\mathrm{C}(\mathrm{P})$ as the first independent variable in models with one, two, and three independent variables when regressed on incidence of late blight in the Columbia Basin (Table 7). Cumulative solar irradiance was identified using forward selection as the independent variable accounting for the most structure $(P=$ 0.003 ) in the regression models at Othello. At Prosser during both time periods, number of rainy days was selected by $R^{2}$ selection method and the Mallow statistic for the one independent variable model, and cumulative solar irradiance was selected as the first variable in the two- and threeindependent variable models (Table 7). Number of rainy days was identified using forward selection as the independent variable accounting for the most variation in late blight incidence $(P=0.009)$ in the

Table 5. (continued from preceding page)

\begin{tabular}{|c|c|c|c|c|c|}
\hline Models & Period & Second variable ${ }^{a}$ & $\operatorname{Pr}>\boldsymbol{F}$ & $R^{2}$ & Adj. $R^{2}$ \\
\hline No. of couplets (rain) & April-July & $\ldots$ & 0.014 & 0.34 & $\ldots$ \\
\hline No. of couplets (rain) & June-July & $\ldots$ & 0.047 & 0.24 & $\ldots$ \\
\hline No. of couplets (rain/cloudy) & April-July & $\ldots$ & 0.022 & 0.31 & $\ldots$ \\
\hline No. of couplets (rain/cloudy) & June-July & $\ldots$ & 0.002 & 0.48 & $\ldots$ \\
\hline \multicolumn{6}{|l|}{ Two variables } \\
\hline \multicolumn{6}{|l|}{ Othello } \\
\hline Solar irradiance & April-July & No. of rainy days & 0.006 & $\ldots$ & 0.43 \\
\hline Solar irradiance & June-July & No. of rainy days & 0.012 & $\ldots$ & 0.37 \\
\hline Solar irradiance & April-July & $\mathrm{FO}^{*}$ & 0.001 & $\ldots$ & 0.53 \\
\hline Solar irradiance & June-July & FO* & 0.002 & $\ldots$ & 0.53 \\
\hline No. of rainy days & April-July & FO & 0.029 & $\ldots$ & 0.29 \\
\hline No. of rainy days & June-July & FO & 0.028 & $\ldots$ & 0.30 \\
\hline FO & April-July & No. of cloudy days & 0.012 & $\ldots$ & 0.37 \\
\hline FO & June-July & No. of cloudy days* & 0.004 & $\ldots$ & 0.45 \\
\hline FO & April-July & No. of cloudy days w/no rain & 0.033 & $\ldots$ & 0.28 \\
\hline FO & June-July & No. of cloudy days w/no rain & 0.020 & $\ldots$ & 0.33 \\
\hline No. of cloudy w/rainy days & April-July & $\mathrm{FO}$ & 0.010 & $\ldots$ & 0.38 \\
\hline No. of cloudy w/rainy days & June-July & FO & 0.005 & $\ldots$ & 0.45 \\
\hline No. of couplets (rain) & April-July & FO & 0.003 & $\ldots$ & 0.48 \\
\hline No. of couplets (rain) & June-July & FO & 0.010 & $\ldots$ & 0.39 \\
\hline No. of couplets (rain/cloudy) & April-July & $\mathrm{FO}$ & 0.008 & $\ldots$ & 0.40 \\
\hline $\mathrm{FO}$ & June-July & No. of couplets (rain/cloudy) & 0.016 & $\ldots$ & 0.35 \\
\hline \multicolumn{6}{|c|}{ (2) } \\
\hline No. of rainy days & April-July & Solar irradiance & 0.021 & $\ldots$ & 0.34 \\
\hline No. of rainy days & June-July & Solar irradiance & 0.057 & $\ldots$ & 0.24 \\
\hline Solar irradiance & April-July & FO* & 0.002 & $\ldots$ & 0.54 \\
\hline Solar irradiance & June-July & FO* & 0.001 & $\ldots$ & 0.58 \\
\hline No. of rainy days & April-July & $\mathrm{FO}^{*}$ & 0.004 & $\ldots$ & 0.48 \\
\hline No. of rainy days & June-July & FO* & 0.003 & $\ldots$ & 0.50 \\
\hline FO & April-July & No. of cloudy days* & 0.006 & $\ldots$ & 0.45 \\
\hline No. of cloudy days & June-July & $\mathrm{FO}^{*}$ & 0.002 & $\ldots$ & 0.55 \\
\hline FO & April-July & No. of cloudy days w/no rain & 0.048 & $\ldots$ & 0.26 \\
\hline FO & June-July & No. of cloudy days w/no rain* & 0.010 & $\ldots$ & 0.41 \\
\hline No. of cloudy w/rainy days & April-July & FO* & 0.001 & $\ldots$ & 0.58 \\
\hline No. of cloudy w/rainy days & June-July & $\mathrm{FO}^{*}$ & 0.001 & $\ldots$ & 0.62 \\
\hline No. of rain couplets & April-July & FO* & 0.005 & $\ldots$ & 0.46 \\
\hline FO & June-July & No. of rain couplets & 0.021 & $\ldots$ & 0.34 \\
\hline No. of rain-cloudy couplets & April-July & FO* & 0.004 & $\ldots$ & 0.49 \\
\hline No. of rain-cloudy couplets & June-July & FO* & 0.001 & $\ldots$ & 0.59 \\
\hline
\end{tabular}


single-regression models at Prosser. Overall, by using the $R^{2}$ selection method and the Mallow's statistic, the two-variable models with solar irradiance and day of FO accounted for as much or more variation for location and time periods and were the best predictors of the dependent variindependent variable models (Table 7).

\section{DISCUSSION}

Solar irradiance and number of rainy fied by linear regression as factors influlumbia Basin. Historical records indicate that reduced solar radiation and rainfall influenced the first late blight epidemic in Europe. The meteorologist Austin Bourke described the summer weather of northwestern Europe in 1845, the first year of the Irish Potato Famine, as everywhere being "cold, sunless, and wetter than normal" (6). This paper is the first report demonstrating a quantitative association of solar irradiance and incidence of late blight in commercial potato fields. Temperature able compared with the single- or threedays during April through July were identiencing incidence of late blight in the Co-

and moisture have previously been quantified as influence factors on late blight development in the field $(13,14,19,20,23,28$, 32,33).

Even though several meteorological and cultural factors influence late blight incidence, such as rainfall, relative humidity, leaf wetness, temperature, wind, cultivar, and various chemical and cultural control practices, it is notable that from 28 to $43 \%$ of the variation for late blight incidence was accounted for by cumulative solar irradiance. Solar irradiance was not expected to account for all of or even a large proportion of late blight incidence; however, it did account for significant variation. When a factor for early occurrence of late blight was used with cumulative solar irradiance, up to $58 \%$ of the variation of late blight incidence was accounted for as determined with multiple regression.

Solar irradiance, temperature, and relative humidity are the most important weather variables that influence survival of $P$. infestans sporangia (29). Solar irradiance is a major factor in reducing longevity of $P$. infestans sporangia and zoospores

Table 6. Regression equations when selected independent variables, including cumulative solar irradiance and number of rainy days at Othello and Prosser, WA, and day of year of first occurrence of late blight in the Columbia Basin, were regressed with incidence of potato late blight in the Columbia Basin

\begin{tabular}{lll}
\hline Independent variables $^{\mathbf{a}}$ & \multicolumn{1}{c}{ Othello } & \multicolumn{1}{c}{ Prosser } \\
\hline SR April-July & $\hat{Y}=492.4-0.17 X$ & $\hat{Y}=510.3-0.16 X$ \\
SR June-July & $\hat{Y}=326.4-0.19 X$ & $\hat{Y}=399.7-0.22 X$ \\
RD April-July & $\hat{Y}=-27.3+2.04 X$ & $\hat{Y}=-40.1+3.06 X$ \\
RD June-July & $\hat{Y}=-2.8+2.57 X$ & $\hat{Y}=-10.5+4.84 X$ \\
SR April-July + FO & $\hat{Y}=498.8-0.14 X_{1}-0.45 X_{2}$ & $\hat{Y}=662.7-0.17 X_{1}-0.64 X_{2}$ \\
SR June-July + FO & $\hat{Y}=404.7-0.18 X_{1}-0.55 X_{2}$ & $\hat{Y}=568.0-0.25 X_{1}-0.68 X_{2}$ \\
RD April-July + FO & $\hat{Y}=62.6+1.21 X_{1}-0.36 X_{2}$ & $\hat{Y}=59.2+2.63 X_{1}-0.48 X_{2}$ \\
RD June-July + FO & $\hat{Y}=89.2+1.49 X_{1}-0.42 X_{2}$ & $\hat{Y}=99.2+4.66 X_{1}-0.58 X_{2}$ \\
CL RD April-July + FO & $\hat{Y}=11.7+1.69 X_{1}-0.27 X_{2}$ & $\hat{Y}=45.7+2.84 X_{1}-0.55$ \\
CL RD June-July + FO & $\hat{Y}=45.5+2.38 X_{1}-0.33 X_{2}$ & $\hat{Y}=98.3+3.99 X_{1}-0.61$ \\
Rain-cloudy couplet Jun-July + FO & $\hat{Y}=86.6-0.42 X_{1}+2.26 X_{2}$ & $\hat{Y}=87.4+7.45 X_{1}-0.48$ \\
\hline
\end{tabular}

a $\mathrm{SR}=$ sum of the daily hourly means of solar radiation $\left(\mathrm{MJ} / \mathrm{m}^{2}\right)$ for specific climate period; $\mathrm{RD}=$ number of rainy days; $\mathrm{FO}=$ day of first occurrence of late blight; and $\mathrm{Cl} \mathrm{RD}=$ number of cloudy days without rain combined with rainy days.

Table 7. Best linear regression modes with one, two, and three independent variables when cumulative solar irradiance (SR), number of rainy days (RD), and day of year of first occurrence of late blight (FO) were regressed on incidence of late blight in the Columbia Basin at two time periods from 1990 to 2007 at Othello and 1990 to 2006 at Prosser as determined by the $R^{2}$ selection method and Mallow statistic $\mathrm{C}(\mathrm{P})$

\begin{tabular}{|c|c|c|c|c|}
\hline Location, period & No. $^{\mathrm{a}}$ & $R^{2}$ & $\mathbf{C}(\mathbf{P})^{2}$ & 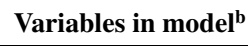 \\
\hline \multicolumn{5}{|l|}{ Othello } \\
\hline \multirow[t]{3}{*}{ April-July } & 1 & 0.425 & 5.582 & SR \\
\hline & 2 & 0.589 & 2.000 & $\mathrm{SR}+\mathrm{FO}$ \\
\hline & 3 & 0.589 & 4.000 & $\mathrm{SR}+\mathrm{RD}+\mathrm{FO}$ \\
\hline \multirow[t]{3}{*}{ June-July } & 1 & 0.321 & 9.126 & SR \\
\hline & 2 & 0.582 & 2.239 & $\mathrm{SR}+\mathrm{FO}$ \\
\hline & 3 & 0.589 & 4.000 & $\mathrm{SR}+\mathrm{RD}+\mathrm{FO}$ \\
\hline \multicolumn{5}{|l|}{ Prosser } \\
\hline \multirow[t]{3}{*}{ April-July } & 1 & 0.374 & 9.832 & RD \\
\hline & 2 & 0.598 & 3.685 & $\mathrm{SR}+\mathrm{FO}$ \\
\hline & 3 & 0.644 & 4.000 & $\mathrm{SR}+\mathrm{RD}+\mathrm{FO}$ \\
\hline \multirow[t]{3}{*}{ June-July } & 1 & 0.312 & 11.938 & $\mathrm{RD}$ \\
\hline & 2 & 0.634 & 2.287 & $\mathrm{SR}+\mathrm{FO}$ \\
\hline & 3 & 0.642 & 4.000 & $\mathrm{SR}+\mathrm{RD}+\mathrm{FO}$ \\
\hline
\end{tabular}

a Number of variables in model.

${ }^{\mathrm{b}} \mathrm{SR}=$ accumulation of mean daily solar radiation for each data period.
$(28,29,31,38)$. Ultraviolet radiation is particularly detrimental to biological organisms $(10,17,35)$ and is likely the damaging fraction of the electromagnetic spectrum to $P$. infestans. Survival of sporangia during spore dispersal is crucial for the spatial increase of late blight (29), and solar irradiance may reduce survival of sporangia in the atmosphere and aerial transmission of sporangia both within and between potato fields. In contrast, longevity of sporangia produced on foliage within the shade of the crop canopy and on abaxial surfaces of leaflets would be less adversely affected by solar radiation than those not shaded. As a result, expansion in size of late blight foci and infection of tubers underneath crop canopies from inoculum produced within the foci are unlikely to be greatly affected by solar radiation. Other direct effects that solar irradiance may have on disease development in the field have not been quantified, such as increased drying of plant surfaces with increased solar irradiance. Number of rainy days was expected to be positively associated with incidence of late blight. Number of rainy days in April and May and an indicator variable representing the occurrence of an epidemic during the preceding year currently are used in logistic regression models to predict the probability of late blight occurring in the Columbia Basin (20). Although late blight has increased in arid regions of Israel $(33,34)$ and the Columbia Basin (11) due to sprinkler irrigation, late blight incidence increases additionally in the Columbia Basin with increasing rainy days. Consecutive days of rain as shown by rain couplets in this study explained one-half the variation $\left(R^{2}=0.51\right)$ of the incidence of late blight at Othello during April through July. However, the reduced solar irradiance incurred by consecutive days of rain may also have contributed to the incidence of late blight.

Separating the effects of reduced solar irradiance and number of rainy days on late blight incidence is difficult because the two frequently occur together. However, they are not mutually inclusive. Substantial rain can occur when it is cloudy, but there may be clouds without rain, rainfall may occur at night with the days before and afterward having no clouds, or a shower may occur during daylight with conditions then becoming cloudless. A substantial number of days at both locations were classified as cloudy with no rain in this study. At Othello during April through July, only one-half of the days $(51 \%)$ that were cloudy had rain and, at Prosser, only $46 \%$ of the cloudy days had rain (Table 3). Moisture from sprinkler irrigation during cloudy days with no rain could supply the moisture needed for sporulation and infection, and cloudy conditions before or after a day with rain might contribute to late blight development, especially with additional sprinkler irrigation. 
Cumulative solar irradiance and number of rainy days did not exhibit collinearity at either Othello or Prosser for both time periods. Furthermore, coefficients of determination were higher and $P$ values were smaller at Othello for regression models with cumulative solar irradiance than for number of rainy days when both variables were separately regressed with late blight incidence (Table 5). Cumulative solar irradiance was identified using several regression model selection techniques that explained more variation than number of rainy days at Othello for models with one, two, and three independent variables (Table 6). Number of rainy days explained the most variation for data collected at Prosser for the model with one independent variable, but cumulative solar irradiance accounted for the most variation in models with two and three independent variables (Tables 5 and 7). The difference between Othello and Prosser may be the due to the climatic differences between the two locations. Othello generally had more rainy days and cloudy days (Table 3) and less cumulative daily solar irradiance on days without rain (Table 1).

A definition of a cloudy day was desired that was based on solar irradiance that would not include a day with a preponderance of sunshine. The definition used based on medium solar irradiance of days with rainfall proved sufficient to help separate the effects of solar irradiance and number of rainy days on late blight incidence. Single-variable regression models for number of cloudy days was correlated with incidence of late blight at both Othello and Prosser but was not correlated when rainy days were omitted (Table 5). However, when number of cloudy days without rain was added to the number of rainy days, a larger proportion of the variation of incidence of late blight was accounted for at both locations than with rain days alone. For example, adding the number of cloudy days with no rain to the number of rain days at Othello during June and July period decreased the $P$ value from 0.027 to 0.003 and increased the $R^{2}$ from 0.27 to 0.44 (Table 5).

Time periods of 1 April to 31 July and 1 June to 31 July were identified as critical in the development of late blight. Potato crops in the Columbia Basin are mostly planted from March to April and harvested from early August through October. The potato canopy in most potato fields in the southern section of the Columbia Basin is closing between rows in early June, which creates a favorable environment for late blight (39), especially during rainfall and sprinkler irrigation. Rains in April through July likely influence an increase of initial inoculum early in the growing season and intra- and interfield spread of late blight. Solar radiation during the same time period would be detrimental to sporangia production, survival, and spread. It is noteworthy that the two-variable regression models that explain the most variation in late blight from both locations occurred in the June through July time period. At Othello, the independent variables were solar irradiance and FO (adjusted $R^{2}=$ 0.53 ) and, at Prosser, the variables were cloudy days without rain combined with number of rain days and FO (adjusted $R^{2}=$ 0.62).

Time of FO of late blight influenced final incidence of late blight because the microclimate within the potato canopy after row closure in irrigated circles favors late blight development and does not vary greatly from year to year in the semiarid environment of the Columbia Basin (19). Spread of the pathogen is also favored by sprinkler irrigation during evening hours in a semiarid environment (26), which would likely be another environmental factor generally consistent among years. Rate of late blight development then may be somewhat constant from year to year due to the microclimate and modified mainly by the application of control practices. Therefore, amount of initial inoculum and time of FO will influence incidence of late blight. Time of FO significantly explained nearly one-third of the variation for incidence of late blight and was a significant second independent variable for the best models in this study (Tables 5 and 7).

Accuracy of detecting the first report of late blight depends on the reliability and thoroughness of individual field persons. Potato fields are monitored several times per week and it is unlikely that late blight foci would not be detected for an extended time period. Field persons have an incentive to detect late blight early so that control tactics for that and adjacent fields can be adjusted to the existing disease pressure. The advantage of the procedure used in this study is that a large number of fields in a relatively large region can be regularly monitored at relatively short intervals, and the procedure is compatible with a regional concept of managing late blight.

Models identified in this study indicate that solar irradiance should be considered when developing predictive models for late blight in the Columbia Basin. Significant relationships with incidence of late blight were each identified for solar irradiance, cloudy days without rain plus rainy days, and consecutive rainy and cloudy days. An early late blight forecasting model in Holland included a factor for cloudiness, which reflected the role of reduced solar irradiance in late blight development (40). Models using solar irradiance could be used concurrently with the logistic regression models currently employed in the Columbia Basin that predict probability of late blight occurrence. The solar irradiance model predicts a different dependent variable, prevalence of late blight in the Columbia Basin. A variable for solar irradiance may be useful in future late blight predictive models and the effect of solar radiation on late blight development deserves further study. Information from this study can be useful in managing late blight in the Columbia Basin in that growers can be made aware of the increased danger from late blight when solar radiation is limited or expected to be limited by cloudy weather. For example, sprinkle application of irrigation water should be limited when cloudy conditions occur when late blight inoculum is present. Also, growers should be alerted when late blight occurs relatively early in the growing season so that timely management tactics can be implemented.

\section{ACKNOWLEDGMENTS}

We thank D. A. Inglis for a critical review of the manuscript.

\section{LITERATURE CITED}

1. Anderson, M. C., Bland, W. L., Norman, J. M., and Diak, G. D. 2001. Canopy wetness and humidity prediction using satellite and synoptic-scale meteorological observations. Plant Dis. 85:1018-1026.

2. Anonymous. 2007. Crop Report. National Agricultural Statistics Service. U. S. Dep. Agric. Washington Field Office, Olympia, WA.

3. Aylor, D. E., Fry, W. E., Mayton, H., and Andrade-Piedra, J. L. 2001. Quantifying the rate of release and escape of Phytophthora infestans sporangia from a potato canopy. Phytopathology 91:1189-1196.

4. Bashi, E., Ben-Joseph, Y., and Rotem, J. 1982. Inoculum potential of Phytophthora infestans and the development of potato late blight. Phytopathology 72:1043-1047.

5. Belsley, D. A., Kuh, E., and Welsch, R. E. 1980. Regression Diagnostics. John Wiley \& Sons, Inc., New York.

6. Bourke, A. 1993. 'The Visitation of God?' The Potato and the Great Irish Famine. The Lilliput Press, Dublin.

7. Coakley, S. M., Boyd, W. S. and Line, R. L. 1984. Development of regional models that use meteorological variables for predicting stripe rust disease on winter wheat. Clim. Appl. Meteorol. 23:1234-1240.

8. Coakley, S. M., Line, R. L., and McDaniel, L. R. 1988. Predicting stripe rust severity on winter wheat using an improved method of analyzing meteorological and rust data. Phytopathology 78:543-550.

9. De Weille, G. A. 1964. Forecasting crop infection by the potato blight fungus. K. Ned. Meteorol. Inst. Meded Verh 82:1-144.

10. Diffey, B. L. 1991. Solar ultraviolet radiation effects on biological systems. Physiol. Med. Biol. 36:299-328.

11. Easton, G. D. 1982. Late blight of potatoes and prediction of epidemics in arid central Washington State. Plant Dis. 66:452-455.

12. Freund, R. J., and Littell, R. C. 2000. SAS System for Regression, Third Edition. SAS Institute, Inc., Cary, NC.

13. Harrison, J. G. 1992. Effects of the aerial environment on late blight of potato foliage- $-\mathrm{a}$ review. Plant Pathol. 41:384-416.

14. Henderson, D., Williams, C.J., and Miller, J.S. 2007. Forecasting late blight in potato crops of southern Idaho using logistic regression analysis. Plant Dis. 91:951-956.

15. Inglis, D. A., Johnson, D. A., Legard, D. E., Fry, W. E., and Hamm, P. B, 1996. Relative resistances of potato clones in response to new and old populations of Phytophthora infestans. Plant Dis. 80:575-578.

16. Inglis, D. A., Powelson, M. L., and Dorrance, 
A. E., 1999. Effect of registered potato seed piece fungicides on tuber-borne Phytophthora infestans. Plant Dis. 83:229-234.

17. Isard, S. A., Dufault, N. S., Miles, M. R., Hartman, G. L., Russo, J. M., De Wolf, E. D., and Morel, W. 2006. The effect of solar irradiance on the mortality of Phakopsora pachyrhizi urediniospores. Plant Dis. 90:941-945.

18. Johnson, D. A., Alldredge, J. R., Hamm, P. B., and Frazier, B. E. 2003. Aerial photography used for spatial pattern analysis of late blight infection in irrigated potato circles. Phytopathology 93:805-812.

19. Johnson, D. A., Alldredge, J. R., and Vakoch, D. L., 1996. Potato late blight forecasting models for the semiarid environment of southcentral Washington. Phytopathology 86:103106.

20. Johnson, D. A., Cummings, T. F., and Hamm, P. B., 1998. Expansion of potato late blight forecasting models for the Columbia Basin of Washington and Oregon. Plant Dis. 82:642645.

21. Johnson, D. A., Cummings, T. F., and Hamm, P. B. 2000. Cost of fungicides used to manage potato late blight in the Columbia Basin: 1996 to 1998. Plant Dis. 84:399-402.

22. Johnson, D. A., Cummings, T. F., Hamm, P. B., Rowe, R. C., Miller, J. S., Thornton, R. E., Pelter, J. Q., and Sorensen, E. J., 1997. Potato late blight in the Colombia Basin: an economic analysis of the 1995 epidemic. Plant Dis. 81:103-106.

23. Lacey, L. 1967. The role of water in the spread of Phytophthora infestans in the potato crop.
Ann. Appl. Biol. 59:245-255.

24. Lambert, D. H., Currier, A. I., and Olanya, M. O. 1998. Transmission of Phytophthora infestans in cut potato seed. Am. J. Potato Res. 75:257-263.

25. Marshall, K. D., and Stevenson, W. R. 1996. Transmission of Phytophthora infestans from infected seed potato tubers to developing sprouts. (Abstr.) Am. Potato J. 73:370-371

26. Miller, J. S., and Johnson, D. A. 2000. Competitive fitness of Phytophthora infestans isolates under semiarid field conditions. Phytopathology 90:220-227.

27. Miller J. S., Johnson D. A., and Hamm P. B., 1995. Aggressiveness of isolates of Phytophthora infestans from the Columbia Basin of Washington and Oregon. Phytopathology 88:190-197.

28. Minogue, K. P., and Fry, W. E. 1981. Effect of temperature, relative humidity, and rehydration rate on germination of dried sporangia of Phytophthora infestans. Phytopathology 71:11811184

29. Mizubuti, E. S. G., Aylor, D. E., and Fry, W. E. 2000. Survival of Phytophthora infestans sporangia exposed to solar radiation. Phytopathology 90:78-84

30. Porter, L. D., and Johnson, D. A. 2003. Survival of Phytophthora infestans in surface water. Phytopathology 94:380-387.

31. Porter, L. D., and Johnson, D. A. 2007. Survival of sporangia of new clonal lineages of Phytophthora infestans in soil under semiarid conditions. Plant Dis. 91:835-841.

32. Rotem, J., and Cohen, Y. 1974. Epidemiologi- cal patterns of Phytophthora infestans under semi-arid conditions. Phytopathology 64:711 714.

33. Rotem, J., Cohen, Y., and Putler, J. 1971 Relativity of limiting and optimum inoculum loads, wetting durations, and temperatures for infection by Phytophthora infestans. Phytopathology 61:275-278.

34. Rotem, J., Palti, J., and Lomas, J. 1970. Effects of sprinkler irrigation at various times of the day on development of potato late blight. Phytopathology 60:839-843.

35. Rotem, J., Wooding, B., and Aylor, D.E. 1985 The role of solar radiation, especially ultraviolet, in the mortality of fungal spores. Phytopathology 75:510-514.

36. Seem, R.C., and Eisensmith, S.P. 1986. What's wrong with the Julian Day? Phytopathology $76: 41$.

37. Stevenson, W. R. 1993. Management of early blight and late blight. Pages 141-148 in: Potato Health Management. R. C. Rowe, ed. American Phytopathological Society, St. Paul, MN.

38. Sunseri, M. A., Johnson, D. A., and Dasgupta, N. 2002. Survival of detached sporangia of Phytophthora infestans exposed to ambient, relative dry atmospheric conditions. Am. J. Potato Res. 79:443-450.

39. Vanderplank, J. E. 1963. Plant Diseases; Epidemics and Control. Academic Press, New York.

40. Van Everdingen, E. 1926. Het verband tusschen de weergesteldheid en de aardappelziekte (Phytophthora infestans). Tijdschr. Plantenziekten 32:129-140. 